O-48 季節性アレルギー性鼻炎（スギ花粉症）に対す る抗IgE抗体（オマリズマブ）の使用経験

○永倉 仁史

ながくら耳鼻咽喉科アレルギークリニック

我国でスギ花粉症に対し抗IgE抗体（ゾレア）が適応 となって初めてのスギ花粉シーズンに重症スギ花粉症に 対しての治療効果を検討した。

2020年スギ花粉シーズン前に, ゾレアの投与を希望し て外来を受診した 27 人に対し, 総 $\operatorname{IgE}$ 抗体, スギ特異的 $\mathrm{IgE}$ 抗体等を測定し適応を判定した。投与可能となった 16 人（平均年齢 36.1 歳, 男 $75 \%$, 女 $25 \%$ ）に対しゾレア を投与した。ゾレア使用適応外となった最も大きな理由 は, 総 $I g E$ 值 $<30 \mathrm{UA} / \mathrm{ml}$ あるいはスギ特異的 $\operatorname{IgE}$ 抗体 $<$ 3+であった。対象者のスギ抗体価は $3+, 4+$ 多く, ヒ ノキ抗体価はスギより低く $2+, 3+$ 古大部分であった。投 与回数は 1 回 $(50 \%) \cdot 2$ 回 $(50 \%)$, 投与間隔は $4 \mathrm{~W}$ 毎 (81\%)・2W毎 $(19 \%)$ ，投与量は150～600mgであった。 併用薬剤はゾレアを使用する必須条件である抗ヒス夕ミ ン薬と点鼻薬を必ず服薬の上投薬した。

治療効果判定のため,「アレルギー日記」,「アンケート 調査」を実施した。その結果, 治療効果は非常に良く, 鼻症状スコアでは大部分が著明に改善を示し, Face Scaleは，0:晴ればれ50\%・+1:50\%, VAS（Visual Analog Scale）は治療前 100 からから治療後 7.43 と著明に改善を 示し治療効果は非常に良く, 効果発現も2 10日で確認 された。副作用は 1 例のみで接種部位の短期間の軽度の 疼痛のみであった。

2020年のスギ花粉シーズンは, 関東においても花粉飛 散量が例年平均より少なく, 症状の強い症例が少ない傾 向を認めたが, 花粉飛散量が少なくても症状の強い重症 を対象として使用した本剤の治療効果は非常に良く, 副 作用も，頻度もわずかで軽度であり治療上全く問題とな らなかった。本剤は重症花粉症に非常に治療効果の高い 治療法であることが確認されたが, 治療費も高額である ため慎重に適応を判断することも必要である。また，本 剂の治療効果は, 今後よりスギ花粉の多い状況において も再度検討することが必要であると判断した。

\section{O-49 重症花粉症に対するオマリズマブの使用経験}

○阪本 浩一, 海野 裕子, 春田 友香, 小杉 祐希, 河合 裕子, 梶本 康幸, 角南貴司子

\section{大阪市立大学医学部耳鼻咽喉科}

スギ花粉症の増加が, 2020年版の鼻アレルギー診療ガ イドラインでも指摘されている。スギ花粉症の治療とし ては, ガイドラインに則って, 抗原の回避, 除去から薬 物療法, 免疫療法, 手術療法が選択されている。特に, 抗ヒスタミン剤は, ステロイド点鼻薬と並んで治療の中 心であり, 初期治療, 飛散期治療に用いられている。ま た，スギとダニに対しては舌下免疫療法が 5 歳以上に使 用可能となっており，アレルギー疾患の進展を予防する 点からも十分期待できる方法と考えられている。スギと ダニの併用舌下免疫の安全性に関しても，その安全性を 担保する報告もあり今後, ダニ, スギの重複例には, 積 極的に併用療法が勧められている。このような状況に, 鼻アレルギーに対して初めての抗体製剂が認可され使用 可能となった。これが，2020年版ガイドラインにも掲載 されている, IgEに対する抗体製剤オマリズマブである。 我々は，2020年の 2 月から 5 月にかけて，重症スギ花粉 症の11例にオマリズマブの投与を行なった。

オマリズマブ投与 11 例の内訳は, 男性 7 歳, 女性 4 名。 年歯令, 12 歳から 49 才であった。症例のIgEは, 48 から $1100 \mathrm{IU} / \mathrm{mL}$ で，一回投与量は，300mgから 600mgであっ た。投与間隔は，4週に 1 回投与が， 9 例， 2 週に 1 回投与 が2例であった。投与回数は，2週に1回投与を行なった 2 例が 6 回。 4 週 1 回投与を行なった 9 例では， 4 回投与が 1 例， 3 回投与うが 3 例， 2 回投与が 4 例， 1 回で終了した ものが1例であった。この一例は, 効果不十分で中止を 希望された例である。全11例とも，オマリズマブは安全 に投与され，特に副作用は認めなかった。治療効果につ いては，1回で投与を中止した症例を除く 10 例では，投 与後, 1 週間程度で自覚症状の改善を認めた。各症例に ついて, 治療の導入経過, 併用治療の内容, 治療効果に ついて報告する。 
O-50 前頭洞より波及した鼻性眼窩内合併症の 1 例

○塩澤 晃人, 伊藤 伸, 佐藤 将盛, 肥後隆三郎

順天堂浦安病院

副鼻腔と眼窩は解剖学的に隣接しており, 副鼻腔に生 じた炎症が眼窩へと及ぶことがある。これを鼻性眼窩内 合併症という。治臨床分類は病態の進展によって眼瞼蜂 巣炎, 眼窩蜂巣炎, 眼窩骨膜下膿瘍, 眼窩内膿瘍, 海綿静 脈洞血栓症の5段階にしばしば分類される（Chandlerら） が，今日では有効な抗菌薬の普及に伴い，海綿静脈洞血 栓症などの進行症例は稀となってきている。形態の特徴 から, 耳鼻咽喉科が取り扱う頻度の高い眼窩骨膜下膿瘍 は幼少児では内側型が多く，年長児から成人では上壁型 が多いといわれている。治療法は適切な抗菌薬の経静脈

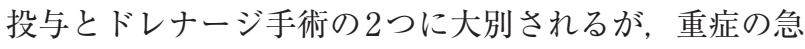
性感染症故に初期治療の選択を誤ると視神経麻痺をはじ めとして不可逆的な後遺症を残す可能性もある。今回わ れわれは基礎疾患のない鼻性眼窩内合併症例を経験した ので報告するとともに，初期治療の選択の適正について も検討する。
O-51当科における眼合併症を来した鼻副鼻腔病変に ついて

$\bigcirc$ 園田 健二, 池田 勝久, 角田 篤信, 安斎 崇, 陶美梨, 荒井 慎平

順天堂大学医学部耳鼻咽喉科学教室

【はじめに】鼻性眼合併症は鼻副鼻腔疾患により視機能 障害をきたす病態である。視機能の温存, 改善のために 速やかな対応を求められる。当科では2018年から現在ま で6件の鼻性眼合併症を経験した。眼窩蜂窩織炎3例, 眼 窩周囲炎 1 例, 外転神経麻痺 1 例, 腫瘍進展による眼球運 動障害 1 例である。年齢は9ケ月から 82 歳と幅広い年齢 に見られており，疾患は4例が急性副鼻腔炎，1例は蝶形 骨洞囊胞感染，1例は悪性リンパ腫であった。急性副鼻 腔炎による眼窩周囲炎以外は外科的加療が行われた。

【代表例提示】症例は 47 歳女性。既往歴に特記事項はな い。来院 3 日前より左眼周囲の疼痛・腫脹が見られ, 近 医内科にて抗菌薬の経静脈投与を受けた。しかし腫脹が 増悪し開眼も困難となったため, 当院紹介となった。初 診時左眼瞼から煩部にかけて著明な腫脹が見られ，開眼 不能な状態であった。中鼻道は閉鎖し, 膿性鼻汁を認め た。副鼻腔CTにて両側沉副鼻腔に低吸収域を認め, 左眼 内側に進展が見られた。急性副鼻腔炎による鼻性眼窩内 合併症と診断。視力ならび眼球運動評価など視機能の評 価は不可能であったため, 抗菌薬と副腎皮質ステロイド の経静脈投与を直ちに開始するとともに，受診当日全身 麻酔下に左内視鏡下鼻副鼻腔手術を行なった。上顎洞を 開放すると著しい排膿を認めた。篩骨洞にも排膿と炎症 所見を認めた。眼球の圧排により，眼窩内側壁の波動を 認め, 炎症による菲薄化が推測された。術後より疼痛・ 腫脹は改善し, 開眼も徐々に可能となり, 術後 6 日で退 院となった。入院時検查で右眼視力 1.2 左眼視力 0.6 と左 視機能の低下が確認されたが, 術後第16日に再検すると 左眼視力は 1.0 まで改善をみた。早期の観血的処置が功を 奏したと思われた。

【考察】眼窩と副鼻腔は解剖学的に近接しており, 鼻副鼻 腔疾患の診断・治療が遅れると不可逆的な障害を残す可 能性がある。鼻性眼合併症に対しては早期の診断及び治 療介入が重要と思われた。 
O-52上壁型眼窩骨膜下膿瘍をきたした両側前頭洞炎 症例

向井 昌功, 五島可奈子, 野島 知人, 瀬尾友佳子, 草間薫, 野中学

東京女子医科大学耳鼻咽喉科

眼窩骨膜下膿瘍は副鼻腔炎による眼窩合併症であり, 膿瘍による眼窩内圧上昇のため複視や視力障害等を呈す る。眼窩骨膜下膿瘍の治療は抗菌薬投与と外科的ドレ ナージである。外科的ドレナージの方法は内側型で内視 鏡下副鼻腔手術（ESS）を，上・下壁型で鼻外切開を選 択することが一般的だが，鼻外切開は確実な膿瘍開放が 可能な反面, 整容面や入院期間の延長が問題となる。そ のため近年ではESSの適応の拡大が模索されている。今 回我々は両側前頭洞炎から波及した眼窩骨膜下膿瘍に対 して内視鏡下拡大前頭洞手術 (Draf type III) を施行した 1例を報告する。症例は75歳男性で, 2019年 12 月X日 (第1病日) から左眼瞼腫脹が出現し, CTで副鼻腔炎の 関与を指摘されて第 6 病日当科に紹介された。身体所見 では左眼瞼腫脹, 左上・下方視で軽度眼球運動障害を認 めた。視力障害は認めなかった。画像所見では両側前頭 洞炎, 左前頭洞外側下壁に骨欠損, それに連続する眼窩 骨膜下膿瘍を認めた。同日より抗菌薬を投与して眼瞼腫 脹と眼球運動障害は改善傾向となったが, 寛解に至らず 第18病日に手術となった。Draf type IIIにより鼻腔と前 頭洞を大きく交通させ，骨欠損部から前頭洞内へ排膿し て治癒させる方針を立てた。両側前頭洞内に充満した debrisを除去後に骨欠損を確認し，眼瞼を圧迫すると褐 色透明の液体が漏出して眼瞼の腫脹が改善した。眼窩内 にdebrisや膿が残存した可能性もあり, 小切開を行った が確認されなかった。鼻内にソーブサンを充填し, 眼窩 内にペンローズドレーンを留置して閉創した。術翌日に ペンローズドレーンを抜去し, 術後3 日目に退院となっ た。眼瞼腫脹と眼球運動障害は共に改善して再発なく経 過している。鼻内創部の上皮化は良好であり，開放した 前頭洞の再閉塞はない。内視鏡下拡大前頭洞手術は上壁 型眼窩骨膜下膿瘍に対して有用な選択肢となる可能性が 示唆された。
O-53鼻性頭蓋内合併症の 3 症例

$\bigcirc$ 宮崎 瑞穂 ${ }^{1}$, 三橋 拓之 ${ }^{2}$, 栗田 卓 ${ }^{1}$, 梅野 博仁 $^{1}$

1久留米大学医学部耳鼻咽喉科・頭頝部外科 ${ }^{2}$ 医療法人厚生会三橋耳鼻咽喉科クリニック

【はじめに】鼻性頭蓋内合併症とは, 副鼻腔から頭蓋内へ 炎症が波及し，髄膜炎・脳膿瘍・硬膜下膿瘍などを引き 起こす疾患である。近年, 画像診断の発達により, 発症 数は減少し稀な疾患となっており，またその死亡率は減 少傾向にある。しかし, 適切な治療がなされないと死亡 に至る重篤な疾患である。我々は死亡例を含む鼻性頭蓋 内合併症の 3 症例を経験したので報告する。【症例 $1 】 12$ 歳男性, 主訴は頭痛・発熱である。両側前頭洞炎に前頭 葉の硬膜外膿瘍を合併していた。症状が出現し5日目か ら抗菌薬の点滴投与を開始し, 内視鏡下鼻副鼻腔手術を 行い, その後内視鏡下拡大前頭洞手術及び穿頭ドレナー ジ術を行った。経過は良好で入院後 86 日目に軽快退院と なった。【症例2】48歳男性, 主訴は発熱・意識障害であ る。両側前頭洞を主座に急性副鼻腔炎を認め, 右前頭洞 後壁の菲薄化，右後頭葉に脳膿瘍，髄膜炎を認めた。症 状が出現し 3 日目から抗菌薬の点滴投与に加えて, 内視 鏡下鼻副鼻腔手術, 鼻外前頭洞手術及び前頭骨の腐骨除 去を行った。経過は良好で入院 62 日目に軽快退院となっ た。【症例3】82歳男性, 主訴は意識障害である。両側前 頭洞・両側篩骨洞に急性副鼻腔炎, 左前頭葉に脳膿瘍形 成, 及び髄膜炎を認めた。症状出現から治療介入まで約 1 か月が経過していた。抗菌薬の点滴投与に加えて, 脳 膿瘍穿頭ドレナージ術を行い, その後, 外切開による両 側鼻外前頭洞根本術と前頭筋骨膜弁による前頭洞充填術 を行ったが, 全身状態の悪化により死亡した。【考察】鼻 性頭蓋内合併症は, 診断・治療介入の遅れや適切な治療 を行わなければ不幸な転帰を辿る，見逃してはならない 疾患である。また, 鼻内手術に加え, 脳外科手術が必要 になることも少なくないため, 脳外科との連携を図り, 早期診断・早期治療介入を行うことが重要である。 
$\bigcirc$ 毛利 博久 $^{1}$, 近藤 健二 $^{2}$

\section{1新宿耳鼻科}

${ }^{2}$ 東京大学医学部耳鼻咽喉科

\section{【はじめに】}

COVID19では高率に嗅覚障害をともなうことが, プロ 野球選手の報道以来日本でも広く認知されている。また 先行研究でCOVID19による嗅覚障害例では嗅裂副鼻腔 に特徴的な陰影を呈することが報告されている。今回嗅 覚障害を主訴に来院，コーンビームCTにて特徵的な $\mathrm{CT}$ 所見を呈したため新宿区コロナ検査センターを紹介, PCR陽性判明のCOVID19患者7名を経験した。

【対象と方法】2020年5月25日-8月4日に嗅覚障害にて来 院した患者 15 名冠状断CTにて

・総鼻道中下部は開存

-上鼻甲介近傍の嗅裂に粘膜浮腫と思われる閉塞像

・両側篩骨洞に院影あるが上顎洞はほぼ正常像

の9例をコロナ検査センター紹介

【結果】上記 9 例中 7 名COVID $19 P C R$ 陽性.陽性率 $77.7 \%$ 。 陽性患者は男 4 名女 3 名年齢21-32歳（20代5名 30 代 2 名）。 職業接客業 3 名歌手 1 名。発症から来院までの日数 $2-8$ 日。 主訴全7例で嗅覚障害, その他症状味覚障害自覚3名, 来 院時発熱 1 名 $\left(\mathrm{BT} 37.2^{\circ} \mathrm{C}\right)$, 受診前発熱 3 名, 鼻閉感 3 名, 鼻の痛み 3 名, 咳嗽 1 名。理学所見では 6 名に咽頭後壁の 軽度発赤, 鼻汁 7 例いずれも認めず。

【考察】嗅覚障害はCOVID19感染の比較的早期から出現 する1症状。Eliezerらは嗅覚障害を呈した40代のCOVID19 患者を報告。患者は鼻閉感にそしく，理学所見上も副鼻 腔炎の所見はそしかったがCT・MRIにて嗅裂から嗅球に かけての炎症性の粘膜浮腫状変化と閉鎖を報告。今回嗅 覚障害患者にCTを施行, この所見を参考にPCR検査を 施行したところ9例中 7例が陽性。COVID19でこのよう な陰影を呈する理由はまだ明らかではないが, SARSCov2はその藏器特異性により上顎洞に比較し篩骨洞や 嗅裂粘膜に対して親和性を持ち，鼻閉や鼻汁の症状は軽 度でありながら篩骨洞優位の急性副鼻腔炎と嗅覚障害を 生じる可能性がある。

【結論】嗅覚障害を伴いCTで特徴的な所見の症例に COVID19PCR検査をしたところ 7/9名（77.7\%）陽性で あった。このような症例ではPCR検査を行うことを強く 勧める。 